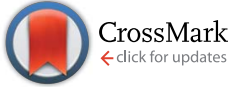

Cite this: Chem. Sci., 2015, 6, 632

Received 28th May 2014

Accepted 5th August 2014

DOI: $10.1039 / c 4 s c 01567 c$

www.rsc.org/chemicalscience

\section{DNA based multi-copper ions assembly using combined pyrazole and salen ligandosides $\uparrow$}

\author{
Meng Su, María Tomás-Gamasa and Thomas Carell*
}

The DNA structure is an ideal building block for the construction of functional nano-objects. In this direction, metal coordinating base pairs (ligandosides) are an appealing tool for the future specific functionalization of such nano-objects. We present here a study, in which we combine the metal ion coordinating pyrazole ligandoside with the interstrand crosslinking salen ligandoside system. We show that both ligandosides, when combined, are able to create stable multi-copper ion complexing DNA double helix structures in a cooperative fashion.

\section{Introduction}

The Watson-Crick base pairing of DNA is a phenomenon that is more and more exploited for the construction of complex two and three dimensional self-assembled nano-objects. ${ }^{1-3}$ Nowadays, sophisticated technologies provide scientists almost total control of the self-assembly process so that basically any desired nano-object can be created using DNA as the building block..$^{4-6}$ The next phase in the field is the functionalization of these objects, thus facilitating access to materials of relevance, e.g. "intelligent" drug delivery devices ${ }^{7}$ or building blocks useful in nano-machines. ${ }^{8}$ One approach for the construction of alternative and functional DNA structures was based on the design of bases showing novel base-pairing schemes, ${ }^{9-11}$ including those held together by hydrogen bonding patterns different from those of the natural base pairs ${ }^{12}$ or by simply hydrophobic interactions. ${ }^{\mathbf{1 3 , 1 4}}$ The development of metal-mediated base pairs (ligandosides) represents a research direction of particular interest in respect to the desired functionalization of DNA. ${ }^{15-17}$ They can add properties to DNA, such as conductivity or magnetism, ${ }^{18-20}$ or they can be used to construct DNA able to perform logic operations. ${ }^{21,22}$

Metal base pairs comprise natural or artificial nucleobases that are able to coordinate a central metal ion. The first group involves the conversion of a natural mismatched base pair into a metal coordinated pair. Examples include the coordination of $\mathrm{Hg}^{2+}$ and $\mathrm{Ag}^{+}$by $\mathrm{T}-\mathrm{T}, \mathrm{U}-\mathrm{U}$ or $\mathrm{C}-\mathrm{A}$ mismatches which goes in hand with the formation of stable metal base pairs. ${ }^{23-26}$

Regarding the artificial base pairs, a plethora of different metal modified double helixes were generated depending on the choice of the synthesized ligandoside. Diverse systems,

Department of Chemistry, Ludwig-Maximilians-University Munich, Butenandtstraße 5-13, 81377, Munich, Germany. E-mail: thomas.carell@cup.uni-muenchen.de

$\uparrow$ Electronic supplementary information (ESI) available. See DOI: $10.1039 / \mathrm{c} 4 \mathrm{sc} 01567 \mathrm{c}$ including monodentate, ${ }^{27,28}$ bidentate $^{29-34}$ as well as homo tridentate ligandosides, ${ }^{35-38}$ which can complex a variety of metal ions (e.g., $\mathrm{Cu}^{2+}, \mathrm{Ni}^{2+}, \mathrm{Pd}^{2+}$ ) have been reported to date. Fig. S1† summarizes current reported structures. Last examples comprise new bimetal base pairs, ${ }^{39,40}$ which in principle would allow to construct DNA structures with heavy metal ion loading.

In 2005, we introduced the salen concept for the construction of a new metal base pair. ${ }^{41-45}$ This ligandoside involves formation of a covalent linkage between the two strands via a bridge established by ethylenediamine, as depicted in Fig. 1a. Due to the formed interstrand crosslink, the salen base pair was proven to be extremely stable after coordination of a copper ion.

In order to broaden this concept and to move away from the linking character of the salen system, we recently reported the pyrazole base pair $(\mathrm{Pz})$ displayed in Fig. 1b. ${ }^{46}$ This ligandoside construction lacks the bridge but still retains the same metal coordination geometry.

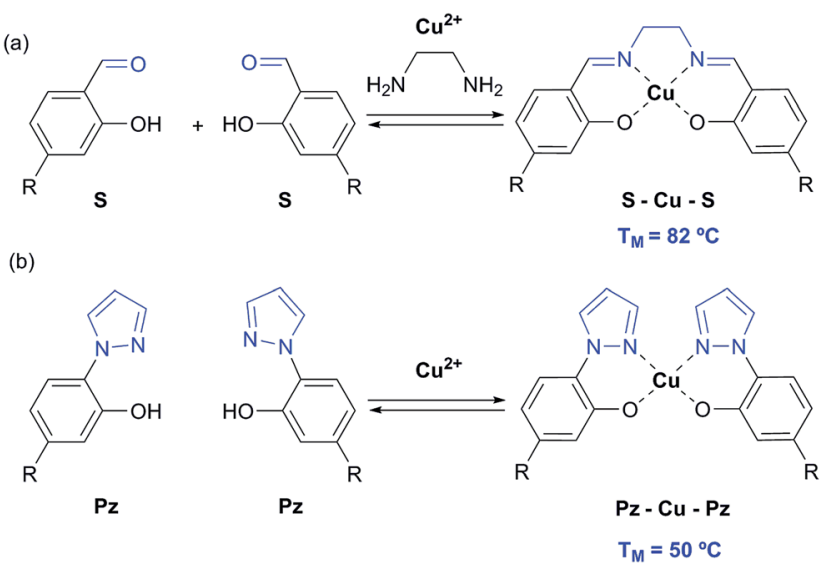

Fig. 1 Depiction of (a) the reversible salen (S) self-base pair; (b) the pyrazole $(\mathrm{Pz})$ self base pair. $\mathrm{R}=$ deoxyribose. 
Here we present stability and selectivity studies with the $\mathrm{Pz}$ ligandoside. We report that by combining the $\mathrm{Pz}$ and the salen ligandosides the generation of stable multi- $\mathrm{Cu}^{2+}$ complexing DNA duplexes becomes possible.

\section{Results and discussion}

We synthesized the pyrazole ligandosides Pz and Pm according to our published procedure. ${ }^{46}$ Table 1 summarizes the modified DNA single strands prepared for this work.

\section{Complexation properties}

To determine the thermal stability of DNA duplexes containing the ligands $\mathrm{Pz}$ and $\mathrm{Pm}$, melting points were measured in the absence and in the presence of copper ions.

For duplexes $\mathbf{1 a} / \mathbf{1} \mathbf{b}$ and $\mathbf{2 a / 2} \mathbf{b}$ having one artificial base pair inserted, a decrease of the melting point value from $49^{\circ} \mathrm{C}\left(T_{\mathrm{M}}\right.$ of the reference duplex $\mathbf{0 a} / \mathbf{0 b}$ containing a GC base pair) to $41^{\circ} \mathrm{C}$ and $42{ }^{\circ} \mathrm{C}$ was observed, respectively. Upon metal complexation, the duplex with the $\mathrm{Pz}-\mathrm{Cu}-\mathrm{Pz}$ complex furnished a melting temperature of $50{ }^{\circ} \mathrm{C}$, slightly above the original $T_{\mathrm{M}}$ of the duplex $\mathbf{0 a} / \mathbf{0 b}$. In contrast, no increase of the $T_{\mathbf{M}}$ value was detected for duplex $\mathbf{2 a} / \mathbf{2 b}\left(42^{\circ} \mathrm{C}\right)$. This result shows that the presence of the phenolic hydroxyl groups and in particular, their ability to become deprotonated, are critical for metal

Table 1 Depiction of the ligandosides Pz and Pm together with the synthesized oligonucleotides needed for this study

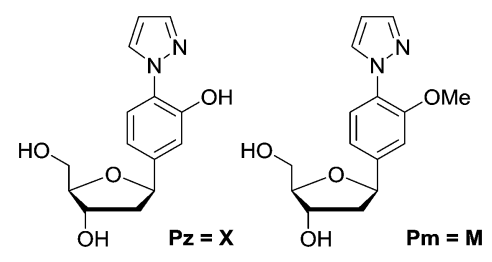

\begin{tabular}{llll}
\hline No. & $5^{\prime}-3^{\prime a}$ & Mass (calc.) & Mass $^{b}$ (exp.) \\
\hline 0a & CAC ATT AGT GTT GTA & 4579.8 & 4576.5 \\
0b & CAC ATT ACT GTT GTA & 4557.8 & 4553.7 \\
1a & CAC ATT AXT GTT GTA & 4588.8 & 4585.0 \\
1b & TAC AAC AXT AAT GTG & 4606.8 & 4602.9 \\
2a & CAC ATT AMT GTT GTA & 4602.8 & 4597.9 \\
2b & TAC AAC AMT AAT GTG & 4620.9 & 4616.3 \\
3a & CAC ATT XXT GTT GTA & 4613.8 & 4611.6 \\
3b & TAC AAC AXX AAT GTG & 4640.9 & 4636.1 \\
4a & GCGCC XXXXXXXXXX GGCCG & 6449.2 & 6452.4 \\
4b & CGGCC XXXXXXXXXX CGCGC & 6369.2 & 6370.8 \\
5a & CAC STT AXT GTS GTA & 4571.8 & 4570.0 \\
5b & TAC SAC AXT AAS GTG & 4589.8 & 4586.8 \\
6a & CAC STT AMT GTS GTA & 4585.8 & 4586.8 \\
6b & TAC SAC AMT AAS GTG & 4603.8 & 4604.2 \\
7a & CATGSTXGSAXCSTXCSTGCA & 6451.1 & 6450.7 \\
7b & TGCASGXASGXTSCXASCATG & 6500.1 & 6500.1 \\
8a & GCGCG XXXXX GGCCG & 4758.9 & 4757.6 \\
8b & CGGCC XXXXX CGCGC & 4678.9 & 4676.6
\end{tabular}

${ }^{a} \mathrm{X}=\mathrm{Pz}, \mathrm{M}=\mathrm{Pm}, \mathrm{S}=$ salen base. ${ }^{b}$ Data from MALDI-TOF mass spectrometry. complexation, which confirms the coordination geometry proposed in Fig. 1b.

In order to investigate in more detail the need for deprotonation, a study of the relationship between duplex thermostability and the $\mathrm{pH}$ value was carried out, using duplexes 1a/1 b and $\mathbf{2 a} / \mathbf{2 b}$. The data are compiled in Fig. 2, S2 and S3 and Table S1.† At pH 6.0, no substantial differences between the presence and absence of copper ions were found. The $T_{\mathrm{M}}$ is approximately $8{ }^{\circ} \mathrm{C}$ lower than the $T_{\mathrm{M}}$ of the canonical duplex $\mathbf{0 a} / \mathbf{0 b}$. At this $\mathrm{pH}$, the phenolic hydroxyl groups are obviously not deprotonated, which blocks $\mathrm{Cu}^{2+}$ complexation. Interestingly, at physiological pH 7.4, a slight difference $\left(51{ }^{\circ} \mathrm{C}\right.$ to $\left.47^{\circ} \mathrm{C}\right)$ regarding the melting point values between $\mathbf{1 a} / \mathbf{1} \mathbf{b}$ without and with $\mathrm{Cu}^{2+}$ was observed. We speculate that, at this $\mathrm{pH}$, half deprotonation takes place, which leads, in the absence of $\mathrm{Cu}^{2+}$, to the formation of a stabilizing $\mathrm{H}$-bonding bridge between the $\mathrm{Pz}-\mathrm{Pz}$ base pair. Upon addition of $\mathrm{Cu}^{2+}$, the copper base pair is formed and is as stable as the $\mathrm{H}$-bonded $\mathrm{Pz}-\mathrm{Pz}$ self pair. At $\mathrm{pH}$ 9.0, the metal-free duplex is less stable, likely because of phenoxide formation followed by charge repulsion. Addition of $\mathrm{Cu}^{2+}$ stabilizes the system, in agreement with formation of the $\mathrm{Pz}-\mathrm{Cu}-\mathrm{Pz}$ base pair.

The overall duplex conformation was further investigated by circular dichroism spectroscopy. All measured CD spectra of DNA containing the $\mathrm{Pz}$ ligandoside in the absence and presence of $\mathrm{Cu}^{2+}$ support the presence of a B-form helix (Fig. S4 and S5 $\dagger$ ).

\section{Selectivity of the Pz base}

Next, the selectivity of the new Pz ligandoside self pair was studied. Melting profiles of a Pz base containing strand 1a with a complementary strand with a canonical base at the opposite position were measured at pH 9.0 (Fig. 3). The results showed that the $\mathrm{Pz}-\mathrm{C}$ situation destabilizes the duplex dramatically while $\mathrm{Pz}-\mathrm{A} / \mathrm{G} / \mathrm{T}$ arrangements give duplexes with lower but similar stability. In the presence of copper ions, the $\mathrm{Pz}-\mathrm{Cu}-\mathrm{Pz}$ metal base pair is by far the most stable structure which is the basis for selective $\mathrm{Cu}^{2+}$-complexation.

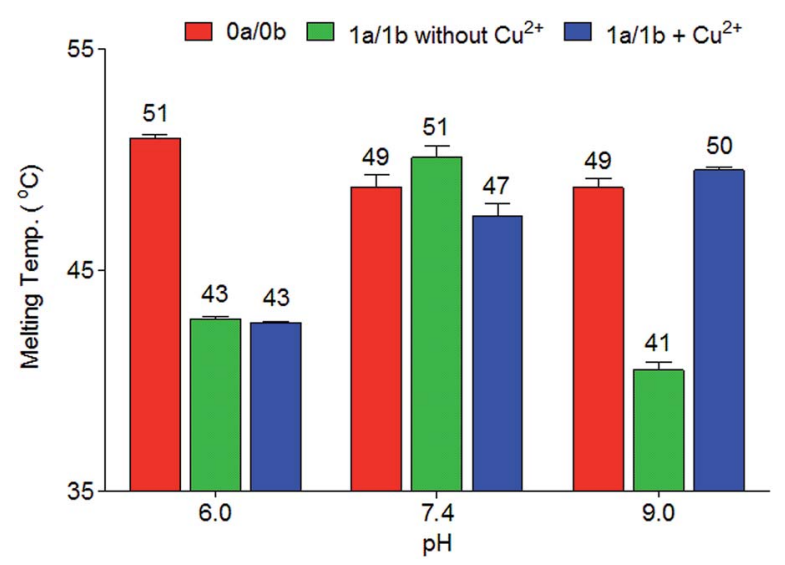

Fig. 2 Melting temperatures of duplexes $0 \mathrm{a} / 0 \mathrm{~b}$ and $1 \mathrm{a} / \mathrm{1b}$ at different $\mathrm{pH}$ values. Conditions: $150 \mathrm{mM} \mathrm{NaCl}, 10 \mathrm{mM} \mathrm{Na} 2 \mathrm{HPO}_{4} / \mathrm{NaH}_{2} \mathrm{PO}_{4}$ buffer $\mathrm{pH}$ 6.0/7.4 or CHES buffer $\mathrm{pH}$ 9.0, $1 \mu \mathrm{M}$ oligonucleotide, with or without $1 \mu \mathrm{M} \mathrm{Cu}^{2+}$, final volume of $200 \mu \mathrm{L}$. 


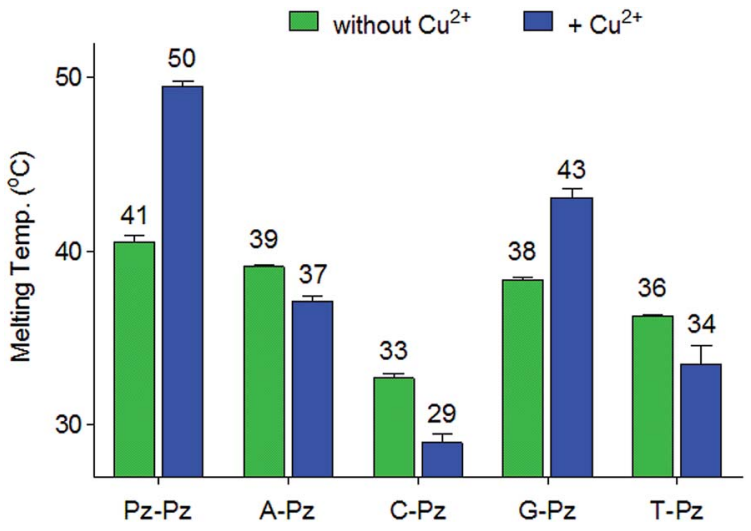

Fig. 3 Melting temperatures of 1 a combined with different counter strands having A, G, C, T or Pz as the counter base. Conditions: $150 \mathrm{mM}$ $\mathrm{NaCl}, 10 \mathrm{mM} \mathrm{CHES}$ buffer $\mathrm{pH}$ 9.0, $1 \mu \mathrm{M}$ oligonucleotide, with or without $1 \mu \mathrm{M} \mathrm{Cu}^{2+}$, final volume of $200 \mu \mathrm{L}$.

\section{Multiple metal ion binding by $(\mathrm{Pz}-\mathrm{Pz})_{n}$-DNA}

To answer the question of whether the Pz ligandoside allows construction of DNA structures containing more than one metal ion stacking on top of each other we prepared oligonucleotides with several consecutive Pz ligandosides (Table 1, duplexes 3a/ $3 \mathbf{b}$ and $4 \mathbf{a} / \mathbf{4 b})$.

As a first approach, two complementary DNA single strands, each containing two neighbouring $\mathrm{Pz}$ pyrazole nucleosides, were hybridized to form the duplex $3 \mathbf{a} / \mathbf{3} \mathbf{b}$. Titration melting profiles are depicted in Fig. 4 . In the absence of copper ions, the $T_{\mathrm{M}}$ of the duplex is decreased by about $11^{\circ} \mathrm{C}\left(T_{\mathrm{M}}=38{ }^{\circ} \mathrm{C}\right.$, Fig. 4 , black line) with respect to the double strand $\mathbf{0 a} / \mathbf{0 b}$ and by $3{ }^{\circ} \mathrm{C}$ with respect to the duplex $\mathbf{1 a} / \mathbf{1} \mathbf{b}$ with only one artificial $\mathrm{Pz}$ base pair.

When one equivalent of $\mathrm{Cu}^{2+}$ was added, the system showed two sigmoidal transitions (Fig. 4, blue line). One transition was detectable at $T_{\mathrm{M}}=38{ }^{\circ} \mathrm{C}$ (corresponding to the $T_{\mathrm{M}}$ for the duplex

\section{$3 a / 3 b$ \\ CACATTPzPzTGTTGTA

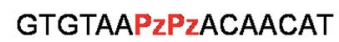

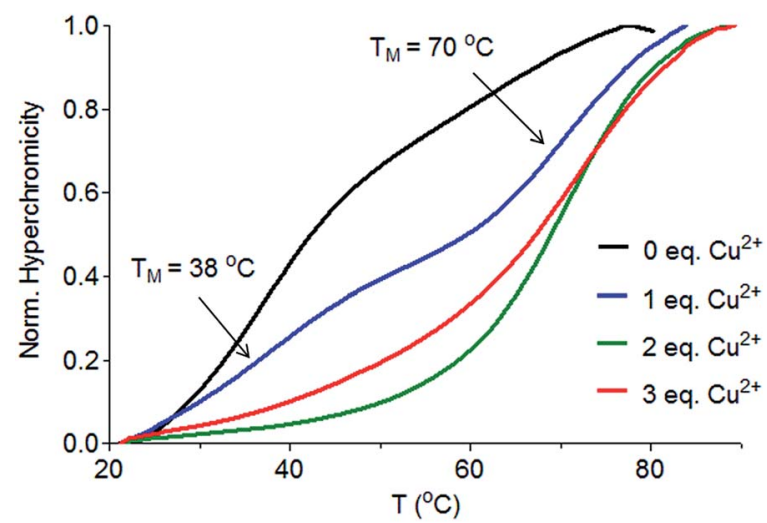

Fig. 4 Schematic depiction of the investigated duplex $3 a / 3 b$ and $\mathrm{Cu}^{2+}$ titration melting profiles of duplex $3 a / 3 b(P z=$ Pyrazole). Conditions: $150 \mathrm{mM} \mathrm{NaCl}, 10 \mathrm{mM}$ CHES buffer $\mathrm{pH}$ 9.0, $1 \mu \mathrm{M}$ oligonucleotide, final volume of $200 \mu \mathrm{L}$. without $\mathrm{Cu}^{2+}$ ) while the second transition appeared at a $T_{\mathrm{M}}$ of $70{ }^{\circ} \mathrm{C}$ (see also Fig. S6†).

These data indicate the presence of two well-defined species in solution. With one equivalent of $\mathrm{Cu}^{2+}$ ions in solution, half of the duplexes contains two metal ions $\left(T_{\mathrm{M}}=70{ }^{\circ} \mathrm{C}\right)$, while the other duplexes feature no metal ion $\left(T_{\mathrm{M}}=38^{\circ} \mathrm{C}\right)$, arguing that $\mathrm{Cu}^{2+}$ complexation by the $\mathrm{Pz}$ ligandoside is a cooperative effect. This is in agreement with the observation of isosbestic points in the UV and CD titration experiments (Fig. S7 and S8 $\dagger$ ). When two or more equivalents of $\mathrm{Cu}^{2+}$ are present, the melting curves exhibit only the transition at $70{ }^{\circ} \mathrm{C}$ (Fig. 4, green and red lines), showing full saturation of all $\mathrm{Cu}^{2+}$ binding sites.

In order to investigate if more than two $\mathrm{Cu}^{2+}$ ions can be arranged in a line, we next studied a duplex with ten consecutive Pz ligandosides, where GC rich DNA sequences were used as the terminus (Table 1 , duplex $\mathbf{4 a} / \mathbf{4 b}$ ).

After hybridization in the presence of $\mathrm{Cu}^{2+}$, the duplex $4 \mathbf{a} / \mathbf{4 b}$ was again subjected to thermal UV analysis. However, due to its high stability, the melting point could not be accurately measured any more under the tested conditions. Therefore, CD titrations (Fig. 5, see also Fig. S9† for titrations at $240 \mathrm{~nm}$ ) and UV titrations (Fig. S10†) at the same concentration were employed to monitor the $\mathrm{Cu}^{2+}$ assembling process. The overlaid CD spectra revealed that the structure of the duplex changes significantly upon increasing $\mathrm{Cu}^{2+}$ complexation. A true isosbestic point is not present any more. Plotting of the ellipticity at $300 \mathrm{~nm}$ against the equivalents of $\mathrm{Cu}^{2+}$ ions displayed, however, a linearly decrease until a $\left[\mathrm{Cu}^{2+}\right] /[$ duplex $]$ ratio of about 10:1 was reached, in agreement with the expected complexation stoichiometry. From the experiments we conclude that the assembly of $10 \times(\mathrm{Pz}-\mathrm{Cu}-\mathrm{Pz})$ is indeed possible. However, the duplex forms a distorted structure that appears to be tolerated by the flexible Pz-self base pair. The

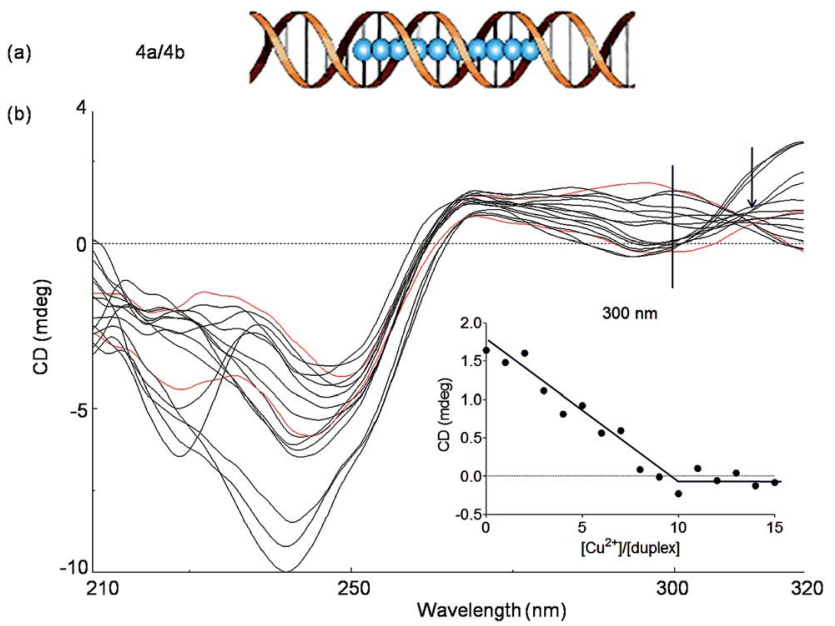

Fig. 5 (a) Schematic depiction of the assembly of $10 \mathrm{Cu}^{2+}$ pyrazole ligandosides inside a DNA duplex $4 a / 4 b$; (b) CD spectral changes of the duplex $4 a / 4 b$ at various concentrations of $\mathrm{Cu}^{2+}$ (from 0 to 15 eq., step of 1 eq.), spectra of 0 eq. and 10 eq. are showed in red. Inset: plot of circular dichroic changes at $300 \mathrm{~nm}$ against the ratio of $\left[\mathrm{Cu}^{2+}\right] /[4 \mathrm{a} / 4 \mathrm{~b}]$. Conditions: $150 \mathrm{mM} \mathrm{NaCl}, 10 \mathrm{mM} \mathrm{CHES} \mathrm{buffer} \mathrm{pH}$ 9.0, $1 \mu \mathrm{M}$ oligonucleotide, final volume of $200 \mu \mathrm{L}$. 
complexation process is certainly not a cooperative event, which explains the absence of clear isosbestic point. We also observe at $240 \mathrm{~nm}$ structural changes beyond the titration of 10 eq. of $\mathrm{Cu}^{2+}$. We believe that these changes are due to additional association of $\mathrm{Cu}^{2+}$ with the multiple Pz-structure. These additional structural changes are not observable at longer wavelength. We therefore examined next how the presence of stiff, while crosslinking, salen ligandosides (S, Fig. 1a) would influence the copper coordination process.

\section{Multiple metal ion binding by hybrid Pz/S containing DNA}

To this end mixed strands were prepared. For an initial study, oligonucleotides containing two salen nucleobases (S) and one additional $\mathrm{Pz}$ nucleobase in the middle were synthesized. In principle, this duplex can complex three metal ions (Table 1, duplex $5 \mathbf{a} / \mathbf{5 b}$ ).

The characteristic changes in the UV/Vis and CD spectrum of duplex $5 \mathbf{a} / \mathbf{5} \mathbf{b}$ that occur upon titration with $\mathrm{Cu}^{2+}$ ions are presented in Fig. 6a, S11 and S12. $\dagger$ The overlaid curves show now isosbestic points again at $\lambda=340$ and $396 \mathrm{~nm}$. A plot of the absorbance at $360 \mathrm{~nm}$ against the equivalents of $\mathrm{Cu}^{2+}$ ions is depicted in Fig. 6b. Initially, when one equivalent of $\mathrm{Cu}^{2+}$ was added, a value of 0.025 for the absorbance was measured. With increasing amounts of $\mathrm{Cu}^{2+}$ (up to three equivalents), the absorbance raised to 0.055 , which is a typical behaviour for copper complexation by a salen ligand. ${ }^{42}$ Further titration did not affect the absorbance any more. A similar trend was observed at $235 \mathrm{~nm}$ (Fig. S13 $\dagger$ ). These results confirm the complexation of three metal ions and the data reflect that the first metal ion is complexed by the $\mathrm{Pz}-\mathrm{Pz}$ pair, followed by complexation of the other two ions by the two salen ligandosides. It is clear that the complexation process by both ligandosides follows a different kinetic scheme.
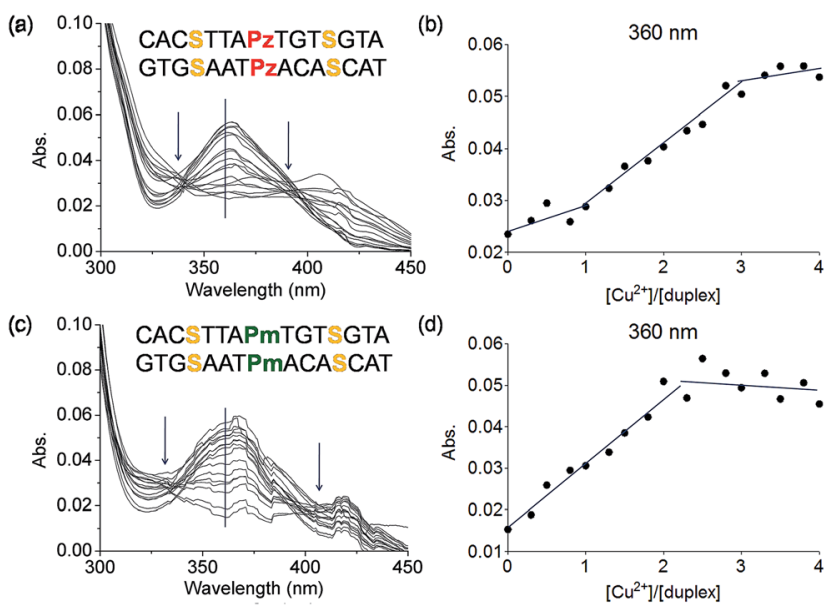

Fig. 6 (a) Overlaid UV spectrum obtained at different concentrations of $\mathrm{Cu}^{2+}$ (from 0 to 4 eq.) of the duplex $5 \mathrm{a} / 5 \mathrm{~b}$ and (b) plot of UV absorbance at $360 \mathrm{~nm}$ against the ration of $\left[\mathrm{Cu}^{2+}\right] /[5 \mathrm{a} / 5 \mathrm{~b}]$; (c) overlaid UV spectrum at different concentrations of $\mathrm{Cu}^{2+}$ (from 0 to 4 eq.) of the duplex $6 \mathrm{a} / 6 \mathrm{~b}$ and (d) plot of UV absorbance at $360 \mathrm{~nm}$ against the ration of $\left[\mathrm{Cu}^{2+}\right] /[6 \mathrm{a} / 6 \mathrm{~b}]$. Conditions: $150 \mathrm{mM} \mathrm{NaCl}, 10 \mathrm{mM} \mathrm{CHES}$ buffer $\mathrm{pH}$ 9.0, $3 \mu \mathrm{M}$ oligonucleotide, 30 eq. ethylenediamine, final volume of $200 \mu \mathrm{L}$.
More experimental support for this hypothesis was obtained when the $\mathrm{Pz}$ nucleoside was replaced by methylated $\mathrm{Pz}(\mathrm{Pm})$, which is unable to coordinate copper ions. UV titration of duplex 6a/6b containing now the Pm instead of the Pz ligandosides showed that the absorbance at $360 \mathrm{~nm}$ increased up to a value of 0.050 after addition of 2 equivalents of $\mathrm{Cu}^{2+}$, characteristic for salen copper complexes (Fig. 6c/d). Further addition of metal ions didn't change the absorbance. As Pm fails to coordinate copper, the ions go directly into the two salen base pairs. Because the increase at $360 \mathrm{~nm}$ for $\mathbf{6 a} / \mathbf{6 b}$ is similar to those for $\mathbf{5 a} / \mathbf{5} \mathbf{b}$, we conclude that two equivalents of $\mathrm{Cu}^{2+}$ are complexed in this case. These observations support the hypothesis, that the $\mathrm{Pz}-\mathrm{Pz}$ base pair is the first ligandoside loaded with a metal ion.

For the characterization of these duplexes, ESI-Mass measurements were performed. Double strand $\mathbf{1 a} / \mathbf{1} \mathbf{b}$, hybridized with copper, provided always two main signals corresponding to the two single strands. We were unable to detect the desired mass peaks of the duplex containing a copper ion inside, confirming that complexation and decomplexation of $\mathrm{Pz}-\mathrm{Pz} \leftrightarrows \mathrm{Pz}-\mathrm{Cu}-\mathrm{Pz}$ is fast. In contrast, the same experiment performed with the duplex $\mathbf{5 a} / \mathbf{5} \mathbf{b}$ with an excess of ethylenediamine and 3 equivalents of $\mathrm{Cu}^{2+}$ showed in the mass spectrum quantitative formation of the duplex containing two copper complexes (Fig. 7 and S14 $\dagger$ ). The third copper ion could not be detected in agreement with fast $\mathrm{Pz}-\mathrm{Cu}-\mathrm{Pz}$ decomplexation. Obviously, and in agreement with earlier data, ${ }^{\mathbf{4 2}}$ in the MS

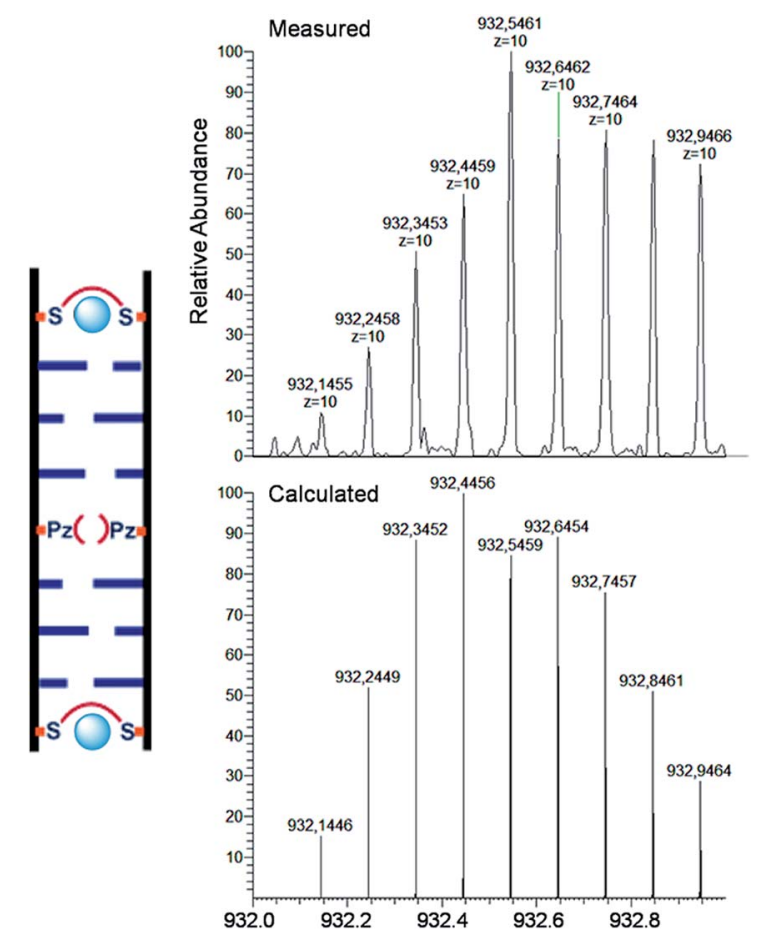

Fig. 7 ESI-Mass spectrum and comparison of experimental data with calculated molecular weights of duplex $6 \mathrm{a} / 6 \mathrm{~b}$ with 2 eq. $\mathrm{Cu}^{2+}$, molecular formula $\mathrm{C}_{316} \mathrm{H}_{384} \mathrm{O}_{176} \mathrm{~N}_{96} \mathrm{P}_{28} \mathrm{Cu}_{2}$. Peaks contain 10 charges (top) compared with calculation (bottom). Conditions: $150 \mathrm{mM}$ $\mathrm{NH}_{4} \mathrm{OAc}, 30 \mu \mathrm{M}$ oligonucleotide, 30 eq. ethylenediamine. 


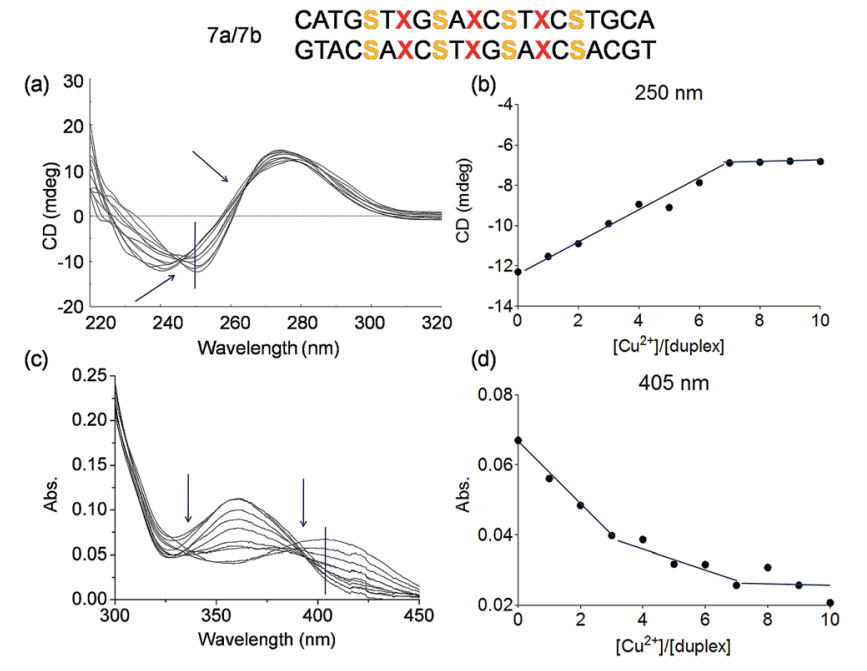

Fig. 8 Schematic depiction of the investigated duplex, $\mathrm{S}=$ salen, $\mathrm{X}=$ pyrazole. (a) Overlaid CD spectrum at different concentrations of $\mathrm{Cu}^{2+}$ (from 0 to 10 eq.) of the duplex $7 a / 7 b$; (b) plot of circular dichroic changes at $250 \mathrm{~nm}$ against the ration of $\left[\mathrm{Cu}^{2+}\right] /[7 \mathrm{a} / 7 \mathrm{~b}]$; (c) overlaid UV spectrum under the same conditions as in (a); (d) plot of UV absorbance at $405 \mathrm{~nm}$ against the ration of $\left[\mathrm{Cu}^{2+}\right] /[7 \mathrm{a} / 7 \mathrm{~b}]$. Conditions: 150 $\mathrm{mM} \mathrm{NaCl}, 10 \mathrm{mM}$ CHES buffer $\mathrm{pH}$ 9.0, $3 \mu \mathrm{M}$ oligonucleotide, 30 eq. ethylenediamine, final volume of $200 \mu \mathrm{L}$.

experiment, only the $\mathrm{Cu}$-salen complexes are stable enough to survive the ESI conditions.

A more complicated scenario was found when four Pz pairs were mixed with three salen pairs in duplex $7 \mathbf{a} / 7 \mathbf{b}$. The complexation of copper ions in this new situation was confirmed by $\mathrm{CD}$ titration. The CD data prove complexation of 7 equivalents of $\mathrm{Cu}^{2+}$ ions within the duplex (Fig. 8a/b; see also Fig. S15† for overlaid UV spectrum). The overlaid CD spectrum shows, despite the complex ligandoside composition of the duplex, two isosbestic points at $246 \mathrm{~nm}$ and $265 \mathrm{~nm}$ arguing for cooperative metal complexation. A plot of the UV absorbance at $405 \mathrm{~nm}$ during metal ion titration is displayed in Fig. 8d (see also Fig. S16 $\dagger$ for absorbance at $360 \mathrm{~nm}$ ). The UV data reveal two different trends which correspond to the two different coordination events established by the Pz and the salen base. Addition of three equivalents of $\mathrm{Cu}^{2+}$ led to a first rather sharp decrease in the absorbance at $405 \mathrm{~nm}$, which corresponds to the first coordination process. With $3 \mathrm{Pz}$ ligandosides we assume again initial complexation of $\mathrm{Cu}^{2+}$ by this ligandoside system. Thereafter, addition of another four equivalents of $\mathrm{Cu}^{2+}$ gave a further change of the UV data. Now, the reduction of the absorbance is slower. With all these evidences in hand, and accordingly to the previous hypothesis and results, we conclude that the Pz pairs complex the copper ions first while the 4 salen ligandosides are filled in the second process.

\section{Catalysis of a Diels-Alder reaction by $\left(\mathrm{Pz}-\mathrm{Cu}^{2+}-\mathrm{Pz}\right)_{n}-\mathrm{DNA}$}

In order to investigate if the multiple $\mathrm{Cu}$-containing DNA strands are able to exhibit some function, e.g. as catalyst, we started to investigate their ability to catalyze a Diels-Alder reaction. For other enantioselective Diels Alder reactions based
Table 2 Results of the catalytic Diels-Alder reaction with ds $8 \mathrm{a} / 8 \mathrm{~b}^{a}$

\begin{tabular}{lllllll}
\hline & & & & \\
\hline
\end{tabular}

${ }^{a}$ See ESI for reaction details. All data are averaged over two experiments. $\mathrm{OTf}=$ trifluoromethanesulfonate.

on $\mathrm{Cu}^{2+}$-ligand-DNA see ref. 47 and 48 and for $\mathrm{Cu}^{2+}$-G-quadruplex see ref. 49.

The D-A reaction between aza-chalcone (1) and cyclopentadiene (2), using duplex $\mathbf{8 a} / \mathbf{8 b}$ (system with five $\mathrm{Cu}^{2+}$ ions complexed up in Pz containing DNA) as a catalyst was selected for this initial study and the results are summarized in Table 2 . For us a central question was if the duplexes, which contain the metal ions in the middle are able to perform the catalysis and whether enantioselectivity can be obtained. We noted that both single and double strands with the Pz-ligands catalyze the reaction in the presence of $\mathrm{Cu}^{2+}$ and in both cases some chirality transfer is observed. At the same time, the complex accelerates the conversion. Copper counter ion and surrounding $\mathrm{pH}$ are also playing a role in the catalytic process. The result shows that the Pz-containing DNA strands can be turned into catalyst. Now, their efficacy and the ee-values obtained for the reaction need to be improved.

\section{Conclusion}

The metal base pair, pyrazole ligandoside, was synthesized and incorporated into oligonucleotides. The ligandoside system shows a pH-dependent complexation behaviour due to the need for deprotonation of the phenolic groups. When the $\mathrm{OH}$ groups are replaced by a methoxy moiety as in the Pm ligandoside, no metal ion coordination is observed. $\mathrm{Cu}^{2+}$ ions stabilize a Pz-Pz containing duplex when compared to a canonical G-C pair, at $\mathrm{pH} 9.0$.

The Pz-Pz ligandoside base pair allows complexation of up to $10 \mathrm{Cu}^{2+}$ ions within a duplex. Better complexation of multiple $\mathrm{Cu}^{2+}$ ions is, however, observed when the unbridged Pz ligandoside is combined with the bridged salen (S) system which seems to add so much integrity and duplex stiffness that the metal ion complexation process is dominated by cooperative effects. The copper ions show a kinetic preference for 
complexing first into the $\mathrm{Pz}-\mathrm{Pz}$ base pair while the salen complex is loaded in a second independent step. This stepwise complexation enables in principle the design of logic gates. The described complexation properties are indeed now the basis for the construction of defined metal ions clusters within oligonucleotides, with the goal to construct multi-metal ion based catalysts and logic gates.

\section{Acknowledgements}

We thank the Alexander von Humboldt Foundation for a postdoctoral fellowship to M. T.-G. Funding for this research was obtained from the Volkswagen Foundation and the DFG (SFB749, TP4 and SFB1032, TPA5).

\section{Notes and references}

1 N. C. Seeman, Nature, 2003, 421, 427-431.

2 S. M. Douglas, H. Dietz, T. Liedl, B. Hogberg, F. Graf and W. M. Shih, Nature, 2009, 459, 414-418.

3 M. Endo, K. Hidaka, T. Kato, K. Namba and H. Sugiyama, J. Am. Chem. Soc., 2009, 131, 15570-15571.

4 S. H. Ko, M. Su, C. Zhang, A. E. Ribbe, W. Jiang and C. Mao, Nat. Chem., 2010, 2, 1050-1055.

5 X. Bai, T. G. Martin, S. H. W. Scheres and H. Dietz, Proc. Natl. Acad. Sci. U. S. A., 2012, 109, 20012-20017.

6 Z.-S. Wu, Z. Shen, K. Tram and Y. Li, Nat. Commun., 2014, 5.

7 E. S. Andersen, M. Dong, M. M. Nielsen, K. Jahn, R. Subramani, W. Mamdouh, M. M. Golas, B. Sander, H. Stark, C. L. P. Oliveira, J. S. Pedersen, V. Birkedal, F. Besenbacher, K. V. Gothelf and J. Kjems, Nature, 2009, 459, 73-76.

8 H. Pei, L. Liang, G. Yao, J. Li, Q. Huang and C. Fan, Angew. Chem., Int. Ed., 2012, 51, 9020-9024.

9 S. A. Benner, Acc. Chem. Res., 2004, 37, 784-797.

10 F. Wojciechowski and C. J. Leumann, Chem. Soc. Rev., 2011, 40, 5669-5679.

11 I. Hirao, M. Kimoto and R. Yamashige, Acc. Chem. Res., 2012, 45, 2055-2065.

12 Z. Yang, F. Chen, J. B. Alvarado and S. A. Benner, J. Am. Chem. Soc., 2011, 133, 15105-15112.

13 A. A. Henry and F. E. Romesberg, Curr. Opin. Chem. Biol., 2003, 7, 727-733.

14 T. Lavergne, M. Degardin, D. A. Malyshev, H. T. Quach, K. Dhami, P. Ordoukhanian and F. E. Romesberg, J. Am. Chem. Soc., 2013, 135, 5408-5419.

15 G. H. Clever and M. Shionoya, Coord. Chem. Rev., 2010, 254, 2391-2402.

16 Y. Takezawa and M. Shionoya, Acc. Chem. Res., 2012, 45, 2066-2076.

17 P. Scharf and J. Müller, ChemPlusChem, 2013, 78, 20-34.

18 K. Tanaka, A. Tengeiji, T. Kato, N. Toyama and M. Shionoya, Science, 2003, 299, 1212-1213.

19 G. H. Clever, S. J. Reitmeier, T. Carell and O. Schiemann, Angew. Chem., Int. Ed., 2010, 49, 4927-4929.
20 S. Liu, G. H. Clever, Y. Takezawa, M. Kaneko, K. Tanaka, X. Guo and M. Shionoya, Angew. Chem., Int. Ed., 2011, 50, 8886-8890.

21 R. Freeman, T. Finder and I. Willner, Angew. Chem., Int. Ed., 2009, 48, 7818-7821.

22 T. Carell, Nature, 2011, 469, 45-46.

23 Y. Miyake, H. Togashi, M. Tashiro, H. Yamaguchi, S. Oda, M. Kudo, Y. Tanaka, Y. Kondo, R. Sawa, T. Fujimoto, T. Machinami and A. Ono, J. Am. Chem. Soc., 2006, 128, 2172-2173.

24 S. Johannsen, S. Paulus, N. Düpre, J. Müller and R. K. O. Sigel, J. Inorg. Biochem., 2008, 102, 1141-1151.

25 A. Ono, S. Cao, H. Togashi, M. Tashiro, T. Fujimoto, T. Machinami, S. Oda, Y. Miyake, I. Okamoto and Y. Tanaka, Chem. Commun., 2008, 44, 4825-4827.

26 T. Funai, Y. Miyazaki, M. Aotani, E. Yamaguchi, O. Nakagawa, S.-i. Wada, H. Torigoe, A. Ono and H. Urata, Angew. Chem., Int. Ed., 2012, 51, 6464-6466.

27 K. Tanaka, Y. Yamada and M. Shionoya, J. Am. Chem. Soc., 2002, 124, 8802-8803.

28 D. Böhme, N. Düpre, D. A. Megger and J. Müller, Inorg. Chem., 2007, 46, 10114-10119.

29 K. Tanaka and M. Shionoya, J. Org. Chem., 1999, 64, 50025003.

30 H. Weizman and Y. Tor, J. Am. Chem. Soc., 2001, 123, 33753376.

31 K. Tanaka, A. Tengeiji, T. Kato, N. Toyama, M. Shiro and M. Shionoya, J. Am. Chem. Soc., 2002, 124, 12494-12498.

32 L. Zhang and E. Meggers, J. Am. Chem. Soc., 2004, 127, 7475.

33 C. Switzer and D. Shin, Chem. Commun., 2005, 41, 13421344.

34 C. Switzer, S. Sinha, P. H. Kim and B. D. Heuberger, Angew. Chem., Int. Ed., 2005, 44, 1529-1532.

35 E. Meggers, P. L. Holland, W. B. Tolman, F. E. Romesberg and P. G. Schultz, J. Am. Chem. Soc., 2000, 122, 1071410715.

36 N. Zimmermann, E. Meggers and P. G. Schultz, J. Am. Chem. Soc., 2002, 124, 13684-13685.

37 D. Shin and C. Switzer, Chem. Commun., 2007, 43, 44014403.

38 B. D. Heuberger, D. Shin and C. Switzer, Org. Lett., 2008, 10, 1091-1094.

39 D. A. Megger, C. Fonseca Guerra, J. Hoffmann, B. Brutschy, F. M. Bickelhaupt and J. Müller, Chem.-Eur. J., 2011, 17, 6533-6544.

40 H. Mei, I. Röhl and F. Seela, J. Org. Chem., 2013, 78, 94579463.

41 G. H. Clever, K. Polborn and T. Carell, Angew. Chem., Int. Ed., 2005, 44, 7204-7208.

42 G. H. Clever, Y. Söltl, H. Burks, W. Spahl and T. Carell, Chem.-Eur. J., 2006, 12, 8708-8718.

43 K. Tanaka, G. H. Clever, Y. Takezawa, Y. Yamada, C. Kaul, M. Shionoya and T. Carell, Nat. Nanotechnol., 2006, 1, 190194.

44 G. H. Clever and T. Carell, Angew. Chem., Int. Ed., 2007, 46, 250-253. 
45 C. Kaul, M. Müller, M. Wagner, S. Schneider and T. Carell, Nat. Chem., 2011, 3, 794-800.

46 M. Su, M. Tomas-Gamasa, S. Serdjukow, P. Mayer and T. Carell, Chem. Commun., 2014, 50, 409-411.

47 G. Roelfes and B. L. Feringa, Angew. Chem., Int. Ed., 2005, 44, 3230-3232.
48 J. Wang, E. Benedetti, L. Bethge, S. Vonhoff, S. Klussmann, J.-J. Vasseur, J. Cossy, M. Smietana and S. Arseniyadis, Angew. Chem., Int. Ed., 2013, 52, 11546-11549.

49 C. Wang, G. Jia, J. Zhou, Y. Li, Y. Liu, S. Lu and C. Li, Angew. Chem., Int. Ed., 2012, 51, 9352-9355. 